\title{
Human Capital Disclosure by the Listed Non- Financial Companies of Bangladesh
}

\author{
Md. Mahabbat Hossain ${ }^{1 *}$, Md. Akhtar Uddin ${ }^{2}$
}

${ }^{1}$ Assistant Professor, Bangladesh Institute of Bank Management (BIBM), Dhaka-1216, BANGLADESH

${ }^{2}$ Professor, Institute of Business Administration (IBA), University of Rajshahi, Rajshahi-6205, BANGLADESH

*E-mail for correspondence: mahabbat@bibm.org.bd

No Conflict of Interest: Declared

\begin{abstract}
Success of an enterprise very much depends on the composition of human capital of the entity. It is now established that human capital is important for the business organization and it may be disclosed in the annual report of the companies. The specific objectives of the paper are to examine the present status of $\mathrm{HC}$ disclosure in corporate annual report of the listed non-financial companies in Bangladesh and to summarize the perceptions of different stakeholders regarding this aspect. Contents analysis has been conducted on annual reports for the year 2008 and 2011 of 82 listed companies in Bangladesh. Perception survey has been conducted on 195 respondents for collecting primary data using five-level Likert scale. Results show that the average disclosure score is below 50 percent and over periods the status is not improving significantly. More than 50 percent companies have achieved less than 40 percent score and there is a large variation in score among the companies' scores. As disclosure of HC items is a need of the stakeholders, companies should be careful about the matter and concern regulators may take initiative to improve the disclosure status of the companies.
\end{abstract}

Keywords: Human Capital, Disclosure, Bangladesh, Content Analysis

\section{INTRODUCTION}

To survive in the modern and competitive era there is no alternative of having human capital (HC). Success of an enterprise very much depends on the composition of human capital of the entity. A set of skilled and sound human resource may ensure efficient use of financial and physical resources. It is expected that in the knowledge-based economy an organization should have human capital. Money, machine, material may not work effectively and efficiently if there is no human capital. In the period of globalization, every organization is facing mounting competition and to cope up with this competition, the organization should build up HC within the organization. Abeysekera (2007) realized that globalization, new technology, relatively free capital, increased competition, changes in customer demands, the demand for innovation and changes in economic and political structures are constantly reshaping the way that business is carried out. To face the present challenges and to avail of the opportunities, a firm should have sufficient skilled and experienced human resources. To design and offer innovative products and services for the customer $\mathrm{HC}$ plays a vital role. Therefore, a trend in management has been the introduction of human capital management and accounting (Abeysekera and Guthrie 2004). It is expected that in order to take advantage of a rapidly changing environment, an enterprise should enhance the accumulation of its $\mathrm{HC}$ and go through the corporate governance to improve its organizational performance (Wu, Lee and Wang 2012). Xinyu (2014) showed that both financial capital and human capital were positively correlated with firm performance. Therefore, such important capital should be disclosed in the corporate annual report of the listed companies for proper communication to the external stakeholders. External stakeholders may consider human capital for choosing the firm. Thus, an entity can enjoy competitive advantages by disseminating information regarding $\mathrm{HC}$ along with physical and financial capital. HC is also important for the investors or lenders to judge the profitability, potentiality and sustainability of the organization. Therefore, company may not ignore the importance of disclosure of human capital for the stakeholders.

\section{Objectives of the Study}

It is now established that human capital is important for the business organization and it may be disclosed in the 
annual report of the companies. Thus, the specific objectives of the paper are:

- to examine the present status of HC disclosure in corporate annual report of the listed non-financial companies in Bangladesh;

- to examine the changes of HC disclosure status over period of time; and

- to summarize the perceptions of different stakeholders regarding $\mathrm{HC}$ disclosure in the corporate annual report of the listed non-financial companies in Bangladesh.

\section{CONCEPT OF Human CAPITAL AND Importance OF DisclosuRE}

Human capital (HC) refers to the individual's education, skills, training, values, experiences, and so forth (Guthrie and Petty 2000). HC may be leveled as human centered assets or employee competence or employee capital. HC involves the capacity to act in a wide variety of situations to create both tangible and intangible assets (Sveiby 1997). These are inherent in people and cannot be owned by organizations (Kavida and Sivakoumar 2009). HC indicates combined capability of employees for solving business problems efficiently. It cannot be incorporated as external agents, nor can they be bought or transferred, packaged or commercialized (Ortiz 2009). Roos and Roos (1997) define $\mathrm{HC}$ as the knowledge, skills and experiences that the employees take with them when they leave the company. Examples of this type of capital are know-how, vocational qualification, career development, training program, equity issue, employee benefits, professional experience, educational level, entrepreneurial skills and spirits etc.

Human capital is part of total intellectual capital (IC). Bontis (1998) stated that intellectual capital (IC) has been considered by many, defined by some, understood by a select few, and formally valued by practically no one (Stewart 1997; Sveiby 1997). Most of the researchers categorize IC into three basic components - human capital (HC), structural capital (SC) and relationship capital (RC) using different levels for them (Johnson 1999; Knight 1999; Bontis et al. 2000; Guthrie and Petty 2000; Brennan 2001; Chen 2001; April et al. 2003; Bozzolan et al. 2003; Abeysekera and Guthrie 2005; Wong and Gardner 2005; Oliveira et al. 2006; Abeysekera 2007; Sujan and Abeysekera 2007; Abeysekera 2008; Ali, Khan and Fatema 2008; Xiao 2008; Dumay 2009; Hossain 2011; Nurunnabi et al. 2011; González-Loureiro and Dorrego 2012; Córcoles 2013; Lipunga 2013; Verbano and Crema 2013; etc.). Sujan and Abeysekera (2007) comment that key components of intellectual capital (IC) are poorly understood, inadequately identified, inefficiently managed and inconsistently reported.

There is a great variation of $\mathrm{HC}$ framework in the previous studies. Wong and Gardner (2005), Vandemaele, Vergauwen and Smits (2005), Guthrie, Petty and Ricceri (2007), Xiao (2008) include five HC items in their studies whereas Guthrie and Petty (2000), Brennan (2001), April, Bosma and Deglon (2003), Goh and Lim (2004) consider six items. Oliveira, Rodrigue and Craig (2006), Bruggen
Vergauwen and Dao (2009) use 10 items in HC framework whereas Davey, Schneider and Davey (2009) use 11 items. Lipunga (2013), Orens, Aerts and Lybaert (2009) frame HC with 16 items whereas Abeysekera and Guthrie (2004), Abeysekera and Guthrie (2005), Abeysekera (2007), Abeysekera (2008) frame with 25 items. It is also found that there are thirty or more $\mathrm{HC}$ items in the previous studies (Nurunnabi, Hossain and Hossain 2011; Batista Fontana and Macagnan 2013). Considering disclosure aspects of Bangladeshi companies, the present study prepared a disclosure checklist with 19 items in HC framework. A summary with number of $\mathrm{HC}$ items used in some previous studies has been presented in Table 1.

Table 1: Number of items in HC framework in the previous studies

\begin{tabular}{|l|c|}
\hline \multicolumn{1}{|c|}{ Prior Study } & $\begin{array}{c}\text { No. of } \\
\text { HC Items }\end{array}$ \\
\hline $\begin{array}{l}\text { Wong and Gardner (2005), Vandemaele, } \\
\text { Vergauwen and Smits (2005), Guthrie, Petty } \\
\text { and Ricceri (2007), Xiao (2008) }\end{array}$ & 5 \\
\hline $\begin{array}{l}\text { Guthrie and Petty (2000), Brennan (2001), } \\
\text { April, Bosma and Deglon (2003), Goh and } \\
\text { Lim (2004) }\end{array}$ & 6 \\
\hline $\begin{array}{l}\text { Sujan, and Abeysekera (2007), Ali, Khan } \\
\text { and Fatima (2008) }\end{array}$ & 7 \\
\hline Dumay (2009), Chander and Mehra (2011) & 8 \\
\hline Tovstiga and Tulugurova (2009) & 9 \\
\hline $\begin{array}{l}\text { Oliveira, Rodrigue and Craig (2006), } \\
\text { Bruggen Vergauwen and Dao (2009) }\end{array}$ & 10 \\
\hline \begin{tabular}{l} 
Davey, Schneider and Davey (2009) \\
\hline and Guthrie (2004), \\
and Guthrie
\end{tabular} & 11 \\
\hline $\begin{array}{l}\text { Guthrie, Steane and Farneti (2005), } \\
\text { (2009) }\end{array}$ & 19 \\
\hline Hossain (2011) & 33 \\
\hline $\begin{array}{l}\text { Abeysekera } \\
\text { Abeysekera } \\
\text { Abeysekera (2007), Abeysekera (2008) }\end{array}$ & 19 \\
\hline Batista Fontana and Macagnan (2013) & 30 \\
\hline Nurunnabi, Hossain and Hossain (2011) & 14 \\
\hline Present study & \\
\hline
\end{tabular}

Source: Researchers' own compilation

Zéghal and Maaloul (2010) state that IC has a positive impact on economic and financial performance. The most short and snappy definitions of intellectual capital is given by Stewart (1997) as 'packaged useful knowledge'. According to his opinion, IC includes an organization's processes, technologies, patents, employees' skills, and information about customers, suppliers and stakeholders. Thus, IC is the possession of knowledge, applied experience, organizational technology, customer relationships, and professional skill that provide a competitive edge in the market (Edvinsson and Malone 1997). Edvinsson and Sullivan (1996) defined IC as knowledge that can be converted into value. Stewart (1997) mentioned that IC refers to the aggregation of all 
knowledge and competences of employees that can bring about competitive advantages. Kavida and Sivakoumar (2009) rightly affirmed that economists call them (IC) knowledge capital, management experts refer to them as intellectual capital, and accountants call them intangible capital or intellectual capital. IC has positive impact on market value and financial performance of firms. Companies' prosperity and sustainability depend on IC also. Therefore, this resource should be recognized appropriately and disclosed properly. IC disclosure is an appropriate approach for companies to meet stakeholders' IC information needs (Bruggen, Vergauwen and Dao 2009). Disclosure of sufficient information has advantages, such as lower costs of capital. IC disclosure can help to increase the value relevance of financial statements (Bruggen, Vergauwen and Dao 2009). The reduction in borrowing costs is due to stakeholders' better estimates of firm risk and a larger pool of potential investors (Bontis 2003; Andriessen 2004; Vergauwen and van Alem 2005).

\section{Disclosure StATUS OF BANGLADESHI COMPANIES}

Several studies have been conducted to show the compliance with mandatory disclosure requirements for Bangladeshi companies. Karim (1995), Hossain (1999) and Hossain, Cooper and Islam (2006) found that the disclosure level of Bangladeshi listed companies is not satisfactory. Hossain and Taylor (1998) found that the mean score of disclosure is 29.33 percent only. As per Rahman (1999), no company of Bangladesh discloses all mandatory information items in their annual reports. Hossain (2000) showed that the average compliance rate for disclosure was 69.05 percent. Akhtaruddin (2005) conducted an empirical investigation of mandatory disclosure by the listed companies in Bangladesh and said that, on average, companies disclose 44 percent of the items of information. Islam (2006) found that the compliance with mandatory accounting standards by Bangladeshi companies is 71 percent. Ahmed and Dey (2009) found a greater variation of disclosure in Bangladeshi companies. Pandit, Hossain and Khatun (2011) report that average disclosure score of mandatory items for the banking companies is 67.34 percent. Hossain (2012) examines financial statements of all Shariah-based banks in Bangladesh and shows that the average compliance rate is 88.11 percent considering all required aspects of financial statements. Hossain and Khatun (2014) check the disclosure compliance of Islamic banks in Bangladesh and their results show that the compliance level of disclosure as per local and international regulations are 94.20 percent and 64.22 percent respectively. There are some studies on the Bangladeshi companies to show the voluntary disclosure status. Hossain, Amirus and Al-Amin (2005) found that only 12 percent Bangladeshi companies disclosed several issues on corporate governance in their annual reports. Hossain, Islam and Andrew (2006) shows that, on average, 8.33 percent Bangladeshi companies disclose social and environmental information in their corporate annual reports. As a voluntary disclosure, average corporate governance disclosure score of Bangladeshi listed companies is 56.04 percent (Bhuiyan and Biswas 2007). Rouf and Hossain (2011) conducted a study on corporate social responsibility disclosure of listed non-financial Bangladeshi companies and result showed that average disclosure score is only 25.64 percent.

Very few studies have been conducted in Bangladesh to show the $\mathrm{HC}$ disclosure practices. $\mathrm{HC}$ disclosure in the annual report is not obligatory for the listed companies in Bangladesh. The companies disclose HC information in the annual report voluntarily. Ali, Khan and Fatima (2008) found that average IC disclosure score of Bangladeshi companies is about 36 percent. They consider only 22 listed companies. Based on 32 leading manufacturing and service sector listed Bangladeshi companies, Khan and Khan (2010) comment that the human capital (HC) reporting practices of these firms are not as low as projected in relation to the total list of items reported. Hossain (2011) found that average disclosure score of intellectual capital items by fuel, power and engineering firms in Bangladesh is 49.89 percent. Nurunnabi, Hossain and Hossain (2011) reveal that the average voluntary IC disclosure score of Bangladeshi non-financial companies is 23.02 percent only. In this situation, the present study will examine human capital disclosure practices by the listed non-financial companies of Bangladesh.

\section{RESEARCH MetHOdOLOGY}

Population of the current study is the listed non-financial companies in Bangladesh. There are two stock exchanges in Bangladesh- Dhaka Stock Exchange (DSE) and Chittagong Stock Exchange (CSE). DSE, older than CSE, is the major stock exchange in Bangladesh. Besides, most of the companies listed on CSE are also listed on DSE. So, the study considers companies listed on DSE. As on June 30, 2008, there were 270 companies (excluding corporate bonds) listed on DSE out of which 189 were non-financial companies. Excluding insurance companies, banks and financial institutions sample units include listed nonfinancial companies under 13 industries (DSE, 2008). Base on purposive sampling technique 82 companies have been selected for the study whose annual reports for the year 2008 and 2011 are readily available. Thus, sample represents 43 percent of total population.

The main objective of the study is to examine HC disclosure practice of the companies. It is found from the literature review that most of the studies in this area use content analysis as a method of research (e.g., Guthrie and Petty 2000; Brennan 2001; April, Bosma and Deglon 2003; Abeysekera and Guthrie 2004; Wong and Gardner 2005; Oliveira, Rodrigue and Craig 2006; Guthrie, Petty and Ricceri 2007; Ali, Khan and Fatima 2008; Bruggen Vergauwen and Dao 2009; Joshi, Ubha and Sidhu 2010; Hossain 2011; Majdalany and Henderson 2013, etc.). This method involves codifying qualitative and quantitative information into pre-defined categories so that a pattern can be derived in presenting and reporting that information (Abeysekera and Guthrie 2005). 
Both primary and secondary data have been used for the present study. Primary data have been collected through a questionnaire to know perceptions of stakeholders. As the fund providers, either equity or loan, are the main external users of corporate information, the researchers collected responses from shareholders, bankers and preparer of annual reports. Respondents have been classified as supplier of information meaning preparer of $A R$, direct user of information meaning fund providers (shareholders and banks). A total of 100 questionnaires have been sent to the preparer of $\mathrm{AR}$ and 200 questionnaires to the direct users requesting to provide their responses. For primary data collection, a questionnaire has been developed following five-level Likert scale where " 1 " for "strongly agree", " 2 " for "agree", "3" for "neutral", " 4 " for "disagree" and " 5 " for "strongly disagree". Respondents had options for putting some suggestions to enhance $\mathrm{HC}$ reporting practices by the listed companies in Bangladesh. Finally, a total number of 59 responses from the suppliers and 136 responses from the direct users have been collected and summarized in this paper. Secondary data have been collected from the corporate annual report (CAR) of concern companies. Besides, various publications of Bangladesh Securities and Exchange Commission (BSEC), Dhaka Stock Exchange (DSE) have been consulted. Moreover, relevant published research articles have also been reviewed.

There is no regulation to govern $\mathrm{HC}$ disclosure practices in the corporate annual reports. Thus, in Bangladesh, HC disclosure in the corporate annual reports of the company is voluntary. Therefore, one key task of the current study is to develop a suitable index containing $\mathrm{HC}$ items which are expected to be reported in corporate annual reports. To do this researcher consulted several prior studies. Based on the prior studies, 19 human capital items have been selected (Appendix).

Weighted and unweighted approaches are the two most recognized methods for determining the level of $\mathrm{HC}$ disclosure. Some of the prior researchers in this field (like, Brennan 2001; Bozzolan, Favotto and Ricceri 2003; Vandemaele, Vergauwen and Smits 2005; Oliveira, Rodrigue and Craig 2006; Sujan, and Abeysekera 2007; Xiao 2008; Orens, Aerts and Lybaert 2009; Nurunnabi, Hossain and Hossain 2011) have used weighted approach in their study. On the other hand, some researches (e.g., April, Bosma and Deglon 2003; Goh and Lim 2004; Guthrie, Petty and Ricceri 2007; Ali, Khan and Fatima 2008; Davey, Schneider and Davey 2009; Hossain 2011; etc.) have used unweighted scoring system. According to Wallace (1988), all disclosure items are equally important to the average users. Therefore, the present study uses unweighted approach for coding $\mathrm{HC}$ items in the disclosure index. If the $\mathrm{HC}$ item is disclosed in the annual report, then it is given ' 1 ' and ' 0 ' if not. The $\mathrm{HC}$ disclosure score for each company is expressed as follows:

$\mathrm{THCD}_{i}=\sum_{j=1}^{n} r_{i j}$
Where,

THCD = the total human capital disclosure score;

$i=$ company $(1,2,3, \ldots \ldots ., 82)$

$j=H C$ item $(1,2,3, \ldots \ldots \ldots . ., 19)$

$r=$ " 1 " if the item is disclosed; " 0 " (zero), if the item is not disclosed.

Some statistical tests have been conducted to present the information more accurately. It is expected that companies will disclose more $\mathrm{HC}$ items in their annual reports with the passes of time. In regard of $\mathrm{HC}$ disclosure, different stakeholders' perceptions may differ. Thus, the following hypotheses have been drawn that will be tested:

H01: There is no difference between extent of $\mathrm{HC}$ disclosure in 2008 and 2011

$\mathrm{H}_{11}$ : There is a difference between extent of $\mathrm{HC}$ disclosure in 2008 and 2011

$\mathrm{H}_{02}$ : There is no difference between perception of suppliers and users of information

$\mathrm{H}_{12}$ : There is a difference between perception of suppliers and users of information

\section{DATA ANALYSIS AND INTERPRETATION}

A total of 19 items were selected under human capital (HC) category. These items may be disclosed in the corporate annual reports of the listed companies of Bangladesh. It is said that these information help the stakeholders of the company to take pragmatic decisions related with the company. Positive information regarding the matter may give competitive advantages to the concerned company. Therefore, existing literatures suggest to provide these information in the corporate annual reports of the companies. Table 2 presents a status of $\mathrm{HC}$ items disclosure in the corporate annual reports for the years 2008 and 2011 of the listed non-financial companies of Bangladesh. It is depicted the table that all of the companies provided information regarding employee and executive compensation in their annual reports of the both years. On the other hand, none of the companies disclosed information regarding recruitment of physically disable person in neither year. But, it is obvious that some physically disable may be fitted for certain positions of the companies. Besides, the companies may show positive approach to the handicap as a part of corporate social responsibility. Most of the companies provide information regarding employee benefits other than salary, employee being thanked and featured and number of employees. But, but it is matter of disappointment that some companies excluded these information over time. Employee share and option ownership plan has been disclosed by 46.91 percent and 53.66 percent companies in 2008 and 2011 respectively. Business environment, technology, process are being changing rapidly. To cope up with the changed scenario, employees are to be trained properly. Surprisingly, only 40.24 percent companies 
reported in 2011 that they have arranged training program for their employees which was 37.8 percent in 2008.

Information regarding entrepreneurial spirits, educational and professional qualification of member of the board and company secretary and value-added statement have been decreased by 5 percent in 2011 than that of 2008. Employee safety and work environment is a sensitive issue and all companies should take sufficient safety measures. It is shown in the Table 2 that only 30.49 percent made some statements regarding employee safety and their work environment. It may be the reason that the companies are concerned about the matter but not disclosing information in the annual report or they are not concerned at all. Knowhow and work-related competencies, professional experience of the employee, vocational qualifications, employee involvement in the community, career development, equity issue (regarding race, gender and religion), expert seniority and age of employees are not been reported by most of the companies. On an average, only 34.02 percent companies disclose HC items in their annual reports of 2011 which was 34.72 percent in 2008 (Table 2).

Table 2: Disclosure score of different HC items ( $\mathrm{n}=82)$

\begin{tabular}{|c|l|c|c|c|}
\hline S/N & HC Items & $\begin{array}{c}2008 \\
(\%)\end{array}$ & $\begin{array}{c}2011 \\
(\%)\end{array}$ & $\begin{array}{c}\text { Increase } \\
(\text { Decrease })\end{array}$ \\
\hline 1 & $\begin{array}{l}\text { Employee and executive } \\
\text { compensation }\end{array}$ & 100 & 100 & 0.00 \\
\hline 2 & $\begin{array}{l}\text { Employee benefits other than } \\
\text { salary }\end{array}$ & 92.68 & 90.24 & $(2.44)$ \\
\hline 3 & $\begin{array}{l}\text { Employees being thanked } \\
\text { and Featured }\end{array}$ & 91.46 & 87.8 & $(3.66)$ \\
\hline 4 & Employee and their numbers & 87.8 & 87.8 & 0.00 \\
\hline 5 & $\begin{array}{l}\text { Employee share and option } \\
\text { ownership plan }\end{array}$ & 46.91 & 53.66 & 6.75 \\
\hline 6 & Training Programs & 37.8 & 40.24 & 2.44 \\
\hline 7 & Entrepreneurial spirits & 37.8 & 32.93 & $(4.87)$ \\
\hline 8 & $\begin{array}{l}\text { Educational and professional } \\
\text { qualification of member of the } \\
\text { board and company secretary }\end{array}$ & 32.93 & 28.05 & $(4.88)$ \\
\hline 9 & Value-added statement & 30.49 & 25.61 & $(4.88)$ \\
\hline 10 & $\begin{array}{l}\text { Employee safety and work } \\
\text { environment }\end{array}$ & 30.49 & 31.71 & 1.22 \\
\hline 11 & $\begin{array}{l}\text { Know-how and work-related } \\
\text { competencies }\end{array}$ & 25.61 & 26.83 & 1.22 \\
\hline 12 & $\begin{array}{l}\text { Professional experience of the } \\
\text { employee }\end{array}$ & 18.29 & 10.98 & $(7.31)$ \\
\hline 13 & Vocational qualifications & 8.54 & 4.88 & $(3.66)$ \\
\hline 14 & $\begin{array}{l}\text { Employee involvement in the } \\
\text { community }\end{array}$ & 7.32 & 6.1 & $(1.22)$ \\
\hline 15 & Career and Development & 6.1 & 10.98 & 4.88 \\
\hline 16 & $\begin{array}{l}\text { Equity Issue (Race, Gender } \\
\text { and Religion) }\end{array}$ & 3.66 & 4.88 & 1.22 \\
\hline 17 & Expert seniority & 1.22 & 3.66 & 2.44 \\
\hline 18 & Age of employees & 1.22 & 1.22 & 0.00 \\
\hline 19 & Equity Issue (Disability) & 0 & 0.00 \\
\hline & Average & 34.72 & 34.02 & $(0.70)$ \\
\hline
\end{tabular}

Source: Study result
Summary of the companies with HC disclosure score is portrays in Table 3. It is depicted from the table that more than 50 percent companies' disclosure scores are in between 20 percent to less than 40 percent. A very few number of companies scores are in between 60 percent to less than 80 percent whereas there is no company who disclose more than 80 percent $\mathrm{HC}$ items in their corporate annual report of either 2008 or 2011. A total number of 11 companies have obtained more than 50 percent score in 2011 (Table 4). The highest score (73.68 percent) is obtained by Singer Bangladesh (Engineering) whereas the second ranked company is Maksons Spinning Mills Limited (Textile). It is also revealed that the companies with higher scored lie in different other industries like "Fuel \& Power", "Pharmaceuticals \& Chemicals" etc (Table 4). There are 9 companies whose disclose scores are below 20 percent (Table 5). Modern Industries (Bd) Limited (Food \& Allied) and Bangla Process (Pharmaceuticals \& Chemicals) joint obtained the lowest HC disclosure score (5.26). Monno Fabrics (Textile), Anwar Galvanizing (Engineering), Samata Leather (Tannery Industries), BD.Autocars (Engineering), Meghna Condensed Milk (Food \& Allied) and Meghna Pet Industries (Food \& Allied) have obtained 15.79 percent HC disclosure score in 2011.

Table 3: Summary of companies with HC disclosure score

\begin{tabular}{|c|c|c|c|c|}
\hline \multirow{2}{*}{ Disclosure Score } & \multicolumn{2}{|c|}{ Companies in 2008} & \multicolumn{2}{c|}{ Companies in 2011} \\
\cline { 2 - 5 } & No. & $\%$ & No. & $\%$ \\
\hline Below $20 \%$ & 5 & 6 & 9 & 11 \\
\hline $20 \%$ to less than $40 \%$ & 48 & 59 & 46 & 56 \\
\hline $40 \%$ to less than $60 \%$ & 24 & 29 & 25 & 30 \\
\hline $60 \%$ to less than $80 \%$ & 5 & 6 & 2 & 3 \\
\hline $80 \%$ and above & 0 & 0 & 0 & 0 \\
\hline Total & $\mathbf{8 2}$ & $\mathbf{1 0 0}$ & $\mathbf{8 2}$ & $\mathbf{1 0 0}$ \\
\hline
\end{tabular}

Source: Study result

Table 4: List of companies whose HC disclosure score in 2011 is more than $50 \%$

\begin{tabular}{|c|l|l|c|}
\hline S/N & Name of Company & Industry & $\begin{array}{c}\text { Score } \\
\text { Obtained (\%) }\end{array}$ \\
\hline 1 & Singer Bangladesh & Engineering & 73.68 \\
\hline 2 & $\begin{array}{l}\text { Maksons Spinning Mills } \\
\text { Limited }\end{array}$ & Textile & 68.42 \\
\hline 3 & Quasem Drycells & Engineering & 57.89 \\
\hline 4 & Summit Power Limited & Fuel \& Power & 57.89 \\
\hline 5 & The Ibn Sina & $\begin{array}{l}\text { Pharmaceuticals } \\
\text { \& Chemicals }\end{array}$ & 57.89 \\
\hline 6 & Libra Infusions Limited & $\begin{array}{l}\text { Pharmaceuticals } \\
\text { \& Chemicals }\end{array}$ & 57.89 \\
\hline 7 & Orion Infusion & $\begin{array}{l}\text { Pharmaceuticals } \\
\text { \& Chemicals }\end{array}$ & 57.89 \\
\hline 8 & Alltex Ind. Ltd. & Textile & 52.63 \\
\hline 9 & $\begin{array}{l}\text { Jamuna Oil Company } \\
\text { Limited }\end{array}$ & Fuel \& Power & 52.63 \\
\hline 10 & $\begin{array}{l}\text { Titas Gas Transmission \& } \\
\text { Dist. Co. Ltd. }\end{array}$ & Fuel \& Power & 52.63 \\
\hline 11 & Rangpur Foundry & Engineering & 52.63 \\
\hline
\end{tabular}

Source: Study result 
Table 5: List of Companies whose HC disclosure score in 2011 is less than $20 \%$

\begin{tabular}{|c|l|l|c|}
\hline S/N & Name of Company & Industry & $\begin{array}{c}\text { Score } \\
\text { Obtained } \\
(\%)\end{array}$ \\
\hline 1 & Monno Fabrics & Textile & 15.79 \\
\hline 2 & Anwar Galvanizing & Engineering & 15.79 \\
\hline 3 & Samata Leather & Tannery Industries & 15.79 \\
\hline 4 & BD.Autocars & Engineering & 15.79 \\
\hline 5 & $\begin{array}{l}\text { Meghna Condensed } \\
\text { Milk }\end{array}$ & Food \& Allied & 15.79 \\
\hline 6 & Meghna Pet Industries & Food \& Allied & 15.79 \\
\hline 7 & Modem Cement Limited & Cement & 10.53 \\
\hline 8 & $\begin{array}{l}\text { Modern Industries } \\
\text { (Bd) Limited }\end{array}$ & Food \& Allied & 5.26 \\
\hline 9 & BangIa Process & $\begin{array}{l}\text { Pharmaceuticals } \\
\text { \& Chemicals }\end{array}$ & 5.26 \\
\hline
\end{tabular}

Source: Study result

Table 6 presents a list of the companies who have made more information in 2011 than that of 2008. Maksons Spinning Mills Limited lays under Textile shows the highest positive trend (31.58 percent) in term of disclosure of HC items in annual report for the year 2011.

Table 6: List of companies whose HC disclosure score has been increased in 2011

\begin{tabular}{|c|l|l|c|c|c|}
\hline $\begin{array}{c}\text { S/ } \\
\mathrm{N}\end{array}$ & Name of Company & Industry & $\begin{array}{c}\mathbf{2 0 0 8} \\
\mathbf{( \% )}\end{array}$ & $\begin{array}{c}\mathbf{2 0 1 1} \\
\mathbf{( \% )}\end{array}$ & $\begin{array}{c}\text { Increased } \\
\mathbf{( \% )}\end{array}$ \\
\hline 1 & Eastern Lubricants & Fuel \& Power & 31.58 & 36.84 & 5.26 \\
\hline 2 & $\begin{array}{l}\text { Desh Garments } \\
\text { Limited }\end{array}$ & Textile & 31.58 & 36.84 & 5.26 \\
\hline 3 & $\begin{array}{l}\text { Jamuna Oil Company } \\
\text { Limited }\end{array}$ & Fuel \& Power & 47.37 & 52.63 & 5.26 \\
\hline 4 & $\begin{array}{l}\text { Titas Gas } \\
\text { Transmission \& Dist. } \\
\text { Co. Ltd. }\end{array}$ & Fuel \& Power & 47.37 & 52.63 & 5.26 \\
\hline 5 & Apex Weaving & Textile & 36.84 & 42.11 & 5.26 \\
\hline 6 & Safko Spinning & Textile & 26.32 & 31.58 & 5.26 \\
\hline 7 & Square Textiles Ltd. & Textile & 42.11 & 47.37 & 5.26 \\
\hline 8 & ACI Limited. & $\begin{array}{l}\text { Pharmaceuticals } \\
\text { \& Chemicals }\end{array}$ & 42.11 & 47.37 & 5.26 \\
\hline 9 & $\begin{array}{l}\text { ACI Formulations } \\
\text { Limited }\end{array}$ & $\begin{array}{l}\text { Pharmaceuticals } \\
\text { \& Chemicals }\end{array}$ & 42.11 & 47.37 & 5.26 \\
\hline 10 & Kohinoor Chemicals & $\begin{array}{l}\text { Pharmaceuticals } \\
\text { \& Chemicals }\end{array}$ & 21.05 & 26.32 & 5.26 \\
\hline 11 & Therapeutics & $\begin{array}{l}\text { Pharmaceuticals } \\
\text { \& Chemicals }\end{array}$ & 26.32 & 31.58 & 5.26 \\
\hline 12 & Eastern Housing & $\begin{array}{l}\text { Services \& } \\
\text { Real Estate }\end{array}$ & 21.05 & 26.32 & 5.26 \\
\hline 13 & $\begin{array}{l}\text { Libra Infusions } \\
\text { Limited }\end{array}$ & $\begin{array}{l}\text { Pharmaceuticals } \\
\text { \& Chemicals }\end{array}$ & 52.63 & 57.89 & 5.26 \\
\hline 14 & $\begin{array}{l}\text { Orion Infusion } \\
\text { \&harmaceuticals } \\
\text { \& Chemicals }\end{array}$ & 52.63 & 57.89 & 5.26 \\
\hline 15 & Singer Bangladesh & Engineering & 63.16 & 73.68 & 10.53 \\
\hline 16 & Dulamia Cotton & Textile & 31.58 & 42.11 & 10.53 \\
\hline 17 & GQ Ball Pen & Miscellaneous & 26.32 & 36.84 & 10.53 \\
\hline 18 & Rangpur Foundry & Engineering & 42.11 & 52.63 & 10.53 \\
\hline 19 & Bangas & Food \& Allied & 26.32 & 42.11 & 15.79 \\
\hline 20 & Apex Tannery & $\begin{array}{l}\text { Tannery } \\
\text { Industries }\end{array}$ & 26.32 & 42.11 & 15.79 \\
\hline 21 & $\begin{array}{l}\text { Maksons Spinning } \\
\text { Mills Limited }\end{array}$ & Textile & 36.84 & 68.42 & 31.58 \\
\hline
\end{tabular}

Source: Study result
Bangas (under Food \& Allied industry) and Apex Tannery (under Tannery Industry) show 15.79 percent improvement in HC disclosure. Singer Bangladesh (Engineering), Rangpur Foundry (Engineering), Dulamia Cotton (Textile), GQ Ball Pen (Miscellaneous) have disclosed 10.53 percent more HC items in 2011 over 2008. Other companies in the list have shown 5.26\% improvement in disclosing such information in their annual reports for the year 2011. The results indicate that some of the companies are showing more interest in presenting $\mathrm{HC}$ items in their annual reports in recent year than the previous year. On the contrary, there are 23 companies who are disclosing lower number of $\mathrm{HC}$ items in the recent year than previous one (Table 7). Power Grid Company of Bangladesh Ltd. (Fuel \& Power) and BEXTEX Ltd. (Textile) have disclosed 26.32 percent lower HC items in 2011 than that of 2008. It is not a good sign that the company will communicate lower number of $\mathrm{HC}$ items over the periods. Rather, all of the companies may try to minimize information asymmetry over period to period.

Table 7: List of companies whose HC disclosure score has been decreased in 2011

\begin{tabular}{|c|l|l|c|c|c|}
\hline $\begin{array}{c}\mathrm{S} / \\
\mathrm{N}\end{array}$ & Name of Company & Industry & $\begin{array}{c}2008 \\
(\%)\end{array}$ & $\begin{array}{c}2011 \\
(\%)\end{array}$ & $\begin{array}{c}\text { Decreased } \\
(\%)\end{array}$ \\
\hline 1 & $\begin{array}{l}\text { Power Grid Company } \\
\text { of Bangladesh Ltd. }\end{array}$ & Fuel \& Power & 63.16 & 36.84 & $(26.32)$ \\
\hline 2 & BEXTEX Ltd. & Textile & 63.16 & 36.84 & $(26.32)$ \\
\hline 3 & BOC Bangladesh & Fuel \& Power & 63.16 & 47.37 & $(15.79)$ \\
\hline 4 & Heidelberg Cement Bd. & Cement & 63.16 & 47.37 & $(15.79)$ \\
\hline 5 & Monno Fabrics & Textile & 31.58 & 15.79 & $(15.79)$ \\
\hline 6 & $\begin{array}{l}\text { Lodern Industries (Bd) } \\
\text { Limited }\end{array}$ & Food \& Allied & 21.05 & 5.26 & $(15.79)$ \\
\hline 7 & Beximco Synthetics & $\begin{array}{l}\text { Pharmaceuticals } \\
\text { \& Chemicals }\end{array}$ & 47.37 & 31.58 & $(15.79)$ \\
\hline 8 & $\begin{array}{l}\text { CMC-Kamal Textile } \\
\text { Mills Ltd }\end{array}$ & Textile & 31.58 & 21.05 & $(10.53)$ \\
\hline 9 & $\begin{array}{l}\text { Information Service } \\
\text { Network Ltd. }\end{array}$ & IT Sector & 47.37 & 36.84 & $(10.53)$ \\
\hline 10 & National Polymer & Engineering & 42.11 & 31.58 & $(10.53)$ \\
\hline 11 & Bata Shoe & $\begin{array}{l}\text { Tannery } \\
\text { Industries }\end{array}$ & 42.11 & 31.58 & $(10.53)$ \\
\hline 12 & Aftab Automobiles" & Engineering & 31.58 & 26.32 & $(5.26)$ \\
\hline 13 & Apex Foods & Food \& Allied & 31.58 & 26.32 & $(5.26)$ \\
\hline 14 & Rahima Food & Food \& Allied & 31.58 & 26.32 & $(5.26)$ \\
\hline 15 & Mithun Knitting & Textile & 31.58 & 26.32 & $(5.26)$ \\
\hline 16 & Prime Textile & Textile & 31.58 & 26.32 & $(5.26)$ \\
\hline 17 & Sonargaon Textiles & Textile & 47.37 & 42.11 & $(5.26)$ \\
\hline 18 & Imam Button & $\begin{array}{l}\text { Pharmaceuticals } \\
\text { \& Chemicals }\end{array}$ & 31.58 & 26.32 & $(5.26)$ \\
\hline 19 & $\begin{array}{l}\text { Summit Alliance Port } \\
\text { Limited }\end{array}$ & $\begin{array}{l}\text { Services \& } \\
\text { Real Estate }\end{array}$ & 47.37 & 42.11 & $(5.26)$ \\
\hline 20 & Aramit Cement & Cement & 42.11 & 36.84 & $(5.26)$ \\
\hline 21 & Anwar Galvanizing & Engineering & 21.05 & 15.79 & $(5.26)$ \\
\hline 22 & Samata Leather & $\begin{array}{l}\text { Tannery } \\
\text { Industries }\end{array}$ & 21.05 & 15.79 & $(5.26)$ \\
\hline 23 & Bd.Thai Aluminium & Engineering & 36.84 & 31.58 & $(5.26)$ \\
\hline
\end{tabular}

Source: Study result

Graph 1 presents scatter graph of disclosure score for the year 2008 and 2011. It is depicted that there is a similarity between disclosure scores of two years but these are not perfectly correlated as there are some out layers. Table 8 presents results of paired-samples T-test. Paired samples correlation 
indicates higher degree of positive correlation (0.813) which is significant at the 0.01 level (2-tailed). As per this table, $t$-value in paired samples test is -0.763 where $p$-value is 0.448 which is not statistically significant. Rank Sum Test (Mann-Whitney Test) results have been presented in Table 9.
It shows that Mann-Whitney $U$ is 3278.500 , Wilcoxon $W$ is 6681.500, Z-value is -0.277 ( $p$-value is 0.782). Thus, null hypothesis is not been rejected and it can be said that there is no significant changes in terms of $\mathrm{HC}$ disclosure status over periods of time.

Graph 1: Scatter graph of disclosure score for the year 2008 and 2011

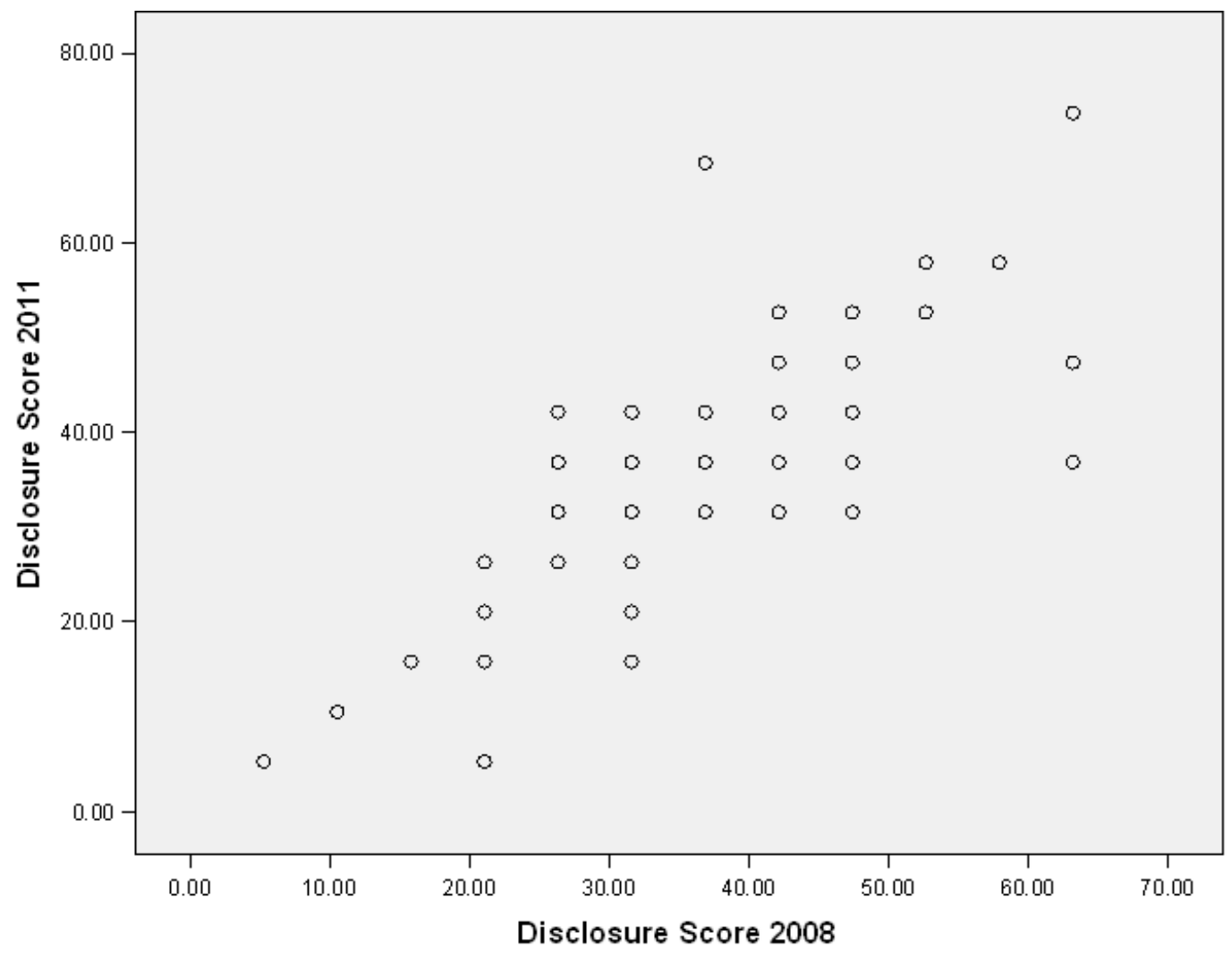

Source: Survey result

Table 8: Equality of two mean test (Paired Samples Test)

\begin{tabular}{|c|c|c|c|c|c|c|c|c|}
\hline \multirow{2}{*}{ Pair } & \multirow{2}{*}{ Mean } & \multirow{2}{*}{ SD } & \multirow{2}{*}{$\begin{array}{l}\text { Std. Error } \\
\text { Mean }\end{array}$} & \multirow{2}{*}{$\mathbf{t}$} & \multirow{2}{*}{ df } & \multirow{2}{*}{$\underset{\text { (2-tailed) }}{\text { Sig. }}$} & \multicolumn{2}{|c|}{ Paired Samples Correlations } \\
\hline & & & & & & & Correlation & Sig. \\
\hline $\begin{array}{l}\text { Disclosure Score } 2011 \text { \& } \\
\text { Disclosure Score } 2008\end{array}$ & -0.70634 & 8.38380 & 0.92584 & -0.763 & 81 & 0.448 & 0.813 & .000 \\
\hline \multicolumn{9}{|c|}{ Mean Value of Disclosure Score $2011=34.02$} \\
\hline \multicolumn{2}{|l|}{ SD of Disclosure Score 2011} & $=13.94148$ & \multicolumn{4}{|c|}{ SD of Disclosure Score 2008} & \multicolumn{2}{|l|}{$=13.43426$} \\
\hline \multicolumn{2}{|l|}{ Std. Error Mean for 2011} & $=1.53958$ & \multicolumn{4}{|c|}{ Std. Error Mean for 2008} & $=1.48357$ & \\
\hline
\end{tabular}

Source: Study result

Table 9: Rank Sum Test (Mann-Whitney Test) Results

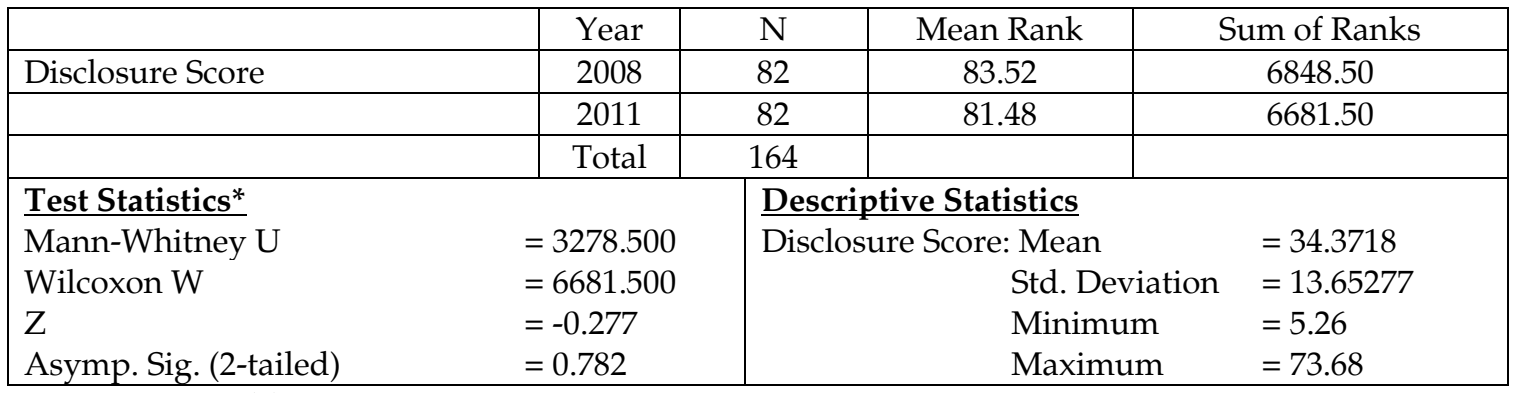

${ }^{*}$ Grouping Variable: Year

Source: Study result 
The researchers conducted a perception survey of different stakeholders for collecting primary data. Suppliers and direct users of information have given their opinions on a five-level Likert scale (i.e. "strongly agree", "agree", "neutral", "disagree" and "strongly disagree"). Opinions of 195 respondents have been summarized in Table 10 and Table 11. Most of the respondents opined that corporate annual report (CAR) is the most suitable way of disseminating company information for the users. As per their opinions, they are currently using information provided in CAR for taking their decisions (Table 10). It is also opined by them that human capital (HC) is the most important factor for business success. Thus, the company may disclose $\mathrm{HC}$ items in their CAR so that they can enjoy competitive advantages over the companies who do not disclose these. Stakeholders believe that disclosure of HC information in CAR is cost-effective and it will add value for the company as well as for the users of information. It is depicted from Table 10 that there is no difference between perception of suppliers and users of information in three cases (Statement No. 3, 4 and 5) as null hypothesis is failed to reject. In other cases, null hypothesis is rejected and thus, perceptions vary between suppliers and users.

Table 10: Perception of stakeholders about HC disclosure in the corporate annual reports of listed non-financial companies in Bangladesh $(\mathrm{n}=195)$

\begin{tabular}{|c|c|c|c|c|c|c|c|c|}
\hline \multirow{2}{*}{$\begin{array}{l}\mathbf{S} / \\
\mathbf{N}\end{array}$} & \multirow[b]{2}{*}{ Statement } & \multicolumn{5}{|c|}{ Opinion on Likert Scale (\%) } & \multicolumn{2}{|c|}{ Mann Whitney Test } \\
\hline & & 1 & 2 & 3 & 4 & 5 & Z Value & P Value \\
\hline 1 & $\begin{array}{l}\text { Corporate annual report (CAR) is the most suitable way } \\
\text { of disseminating company information for the users }\end{array}$ & 39 & 43 & 14 & 4 & 0 & -2.498523252 & $0.012471196^{*}$ \\
\hline 2 & $\begin{array}{l}\text { Investors use information provided in CAR of a } \\
\text { company before taking investment decision }\end{array}$ & 30 & 57 & 11 & 2 & 0 & -2.954076964 & $0.003136058^{* *}$ \\
\hline 3 & $\begin{array}{l}\text { Lenders use information provided in CAR of a company } \\
\text { before taking lending decision }\end{array}$ & 33 & 54 & 10 & 3 & 0 & -0.075518206 & 0.939802413 \\
\hline 4 & $\begin{array}{l}\text { Regulators and others use information provided in CAR } \\
\text { of a company before taking any decision }\end{array}$ & 14 & 71 & 13 & 2 & 0 & -0.001736283 & 0.998614648 \\
\hline 5 & $\begin{array}{l}\text { Human capital (IC) is the most important factor for } \\
\text { business success }\end{array}$ & 23 & 45 & 26 & 6 & 1 & -1.122194702 & 0.261779665 \\
\hline 6 & $\begin{array}{l}\text { Regulators should make it mandatory to disclose HC } \\
\text { items in CAR }\end{array}$ & 38 & 36 & 10 & 15 & 0 & -6.261283029 & 3.81823E-10** \\
\hline 7 & Disclosure of HC information in CAR is cost-effective & 16 & 47 & 27 & 10 & 0 & -4.240863321 & $2.22662 \mathrm{E}-05^{* *}$ \\
\hline 8 & $\begin{array}{l}\text { Disclosure of HC will add value for the company and } \\
\text { the users of information }\end{array}$ & 45 & 39 & 13 & 3 & 0 & 91446 & 0.000 \\
\hline
\end{tabular}

Note: Number of respondents as suppliers 59 and as direct users 136 and total 195

*and ${ }^{* *}$ represent significance levels of 5 percent and 1 percent, respectively (2-tailed)

Source: Survey result

Table 11 presents the opinions of the stakeholders regarding different items of $\mathrm{HC}$ which may be disclosed in the annual report. It is depicted from the table that most of the respondents given their opinions to disclosure different HC items in the CAR. Similar type of perception has been found in the earlier study of Hossain, Khan and Yesmin (2004). A very few portions of them disagree to disclose some of the items. On an average, 38 percent respondents "strongly agree" to provide information regarding $\mathrm{HC}$ whereas 44 percent of them "agree" to disclose these items (Table 11). Only 1 percent "strongly disagree" to disclose such items in annual reports of the listed companies while 3 percent "disagree" with disclosure. Indifferent responses regarding "agree" or "disagree" have given by 14 percent of the respondents. Therefore, listed companies may disclose all of the $\mathrm{HC}$ items in their annual reports to meet information requirements of the stakeholders. Positive information regarding $\mathrm{HC}$ may add value for the company. Non-disclosure of such items may be considered by the investors and lenders as unavailable non-existence of such aspects. Mann-Whitney test results show that in nine cases (Item No. 1,2,3,5,6,7,14,16 and 17) null hypothesis has been rejected while in remaining cases null hypothesis has not been rejected (Table 11). It indicates that for some aspects there is no difference between the perceptions of suppliers and users of information while for some aspects they provided different opinions.

In the questionnaire for perception survey, respondents had options for putting some suggestions to enhance HC disclosure practices by the listed companies in Bangladesh. Thus, they have put forwarded some suggestions regarding the matter. They proposed that regulators may take steps to ensure harmonization in disclosure of information and government may take necessary steps to amend the concern regulations for proper disclosure of $\mathrm{HC}$ information in the corporate annual reports of the listed companies of Bangladesh. 
Table 11: Perception of stakeholders about disclosure of different HC items $(n=195)$

\begin{tabular}{|c|c|c|c|c|c|c|c|c|}
\hline \multirow[t]{2}{*}{$\mathbf{S} / \mathbf{N}$} & \multirow{2}{*}{$\begin{array}{ll}\text { Statement } & \text { Respondents' Perception } \\
\end{array}$} & \multicolumn{5}{|c|}{ Opinion on Likert Scale (\%) } & \multicolumn{2}{|c|}{ Mann Whitney Test } \\
\hline & & 1 & 2 & 3 & 4 & 5 & Z-Value & P Value \\
\hline 1. & Know-how and work-related competencies & 33 & 47 & 19 & 1 & 0 & -5.055550746 & $4.2915 \mathrm{E}-07^{* *}$ \\
\hline 2. & Vocational qualifications & 22 & 54 & 19 & 5 & 1 & -3.482544661 & $0.000496672^{* *}$ \\
\hline 3. & Career and Development & 27 & 58 & 12 & 3 & 1 & -2.993538989 & $0.002757623^{* *}$ \\
\hline 4. & Training Programs & 47 & 49 & 3 & 1 & 0 & -1.544681871 & 0.122423232 \\
\hline 5. & Equity Issue (Race, Gender and Religion) & 23 & 50 & 16 & 11 & 3 & -3.695680681 & $0.000219298^{* *}$ \\
\hline 6. & Equity Issue (Disability) & 14 & 47 & 28 & 11 & 1 & -3.640889456 & $0.000271698^{* *}$ \\
\hline 7. & Employees being thanked and Featured & 26 & 54 & 17 & 3 & 0 & -2.130024226 & $0.033169613^{*}$ \\
\hline 8. & Employee involvement in the community & 13 & 72 & 12 & 3 & 1 & -1.897947781 & 0.057702961 \\
\hline 9. & Employee and executive compensation & 46 & 44 & 7 & 3 & 1 & -0.458606979 & 0.646516424 \\
\hline 10. & Employee benefits other than salary & 55 & 37 & 5 & 3 & 1 & -0.523170532 & 0.600855586 \\
\hline 11. & Employee share and option ownership plan & 40 & 37 & 18 & 5 & 2 & -0.54186391 & 0.58791226 \\
\hline 12. & Value-added statement & 54 & 28 & 13 & 5 & 0 & -0.193196593 & 0.846805007 \\
\hline 13. & Employee and their numbers & 48 & 41 & 8 & 3 & 0 & -0.053320329 & 0.957476683 \\
\hline 14. & $10 \mathrm{~s} \cdot \mathrm{i}$ of & 40 & 56 & 4 & 0 & 0 & -3.44112385 & $0.000579303^{* *}$ \\
\hline 15. & $\begin{array}{l}\text { Educational and professional qualification of member of } \\
\text { the board and company secretary }\end{array}$ & 67 & 26 & 7 & 0 & 0 & -0.135704564 & 0.89205484 \\
\hline 16. & Expert st & 36 & 43 & 21 & 0 & 0 & -3.795218277 & $0.000147514^{* *}$ \\
\hline 17. & Age of employees & 11 & 44 & 42 & 3 & 0 & -2.01948748 & $0.043436577^{*}$ \\
\hline 18. & Entrepreneurial spirits & 48 & 37 & 15 & 0 & 0 & -0.06949387 & 0.944596512 \\
\hline 19. & Employee safety and work environment & 66 & 28 & 6 & 0 & 0 & -0.565132294 & 0.571983784 \\
\hline & Average & 38 & 44 & 14 & 3 & 1 & & \\
\hline
\end{tabular}

Note: Number of respondents as suppliers 59 and as direct users 136 and total 195

*and ** represent significance levels of 5 percent and 1 percent, respectively (2-tailed)

Source: Survey result

\section{CONCLUSION}

It is opined by the scholar that success of an enterprise very much depends on the composition of human capital of the entity in the competitive market nowadays. Efficient human resource may ensure proper use of financial and physical resources. Therefore, it is expected that the company, who has such precious asset, will disclose such items in the annual report. Therefore, the main objective of the paper is to examine the present status of HC disclosure. Results show that the average disclosure score is below 50 percent and over periods the status is not improving significantly. More than 50 percent companies have achieved less than 40 percent score and there is a large variation in score among the companies (the highest score 73.68 percent the lowest score is 5.26 percent). There is no significant positive change over time in disclosing $\mathrm{HC}$ items in the corporate annual reports of the listed companies. As disclosure of $\mathrm{HC}$ items is a need of the stakeholders, companies may be careful about the matter. An initiative may be taken by the concern regulators to improve disclosure status of the companies. Harmonization in disclosure pattern among the companies is also expected by the stakeholders. A different picture may be depicted if study covers all types of companies and perception of all types of stakeholders. Thus, a separate study may be conducted in this area considering all types of industries and opinions from all groups of stakeholders.

\section{REFERENCES}

Abeysekera, I \& Guthrie, J. 2004. Human capital reporting in a developing nation. British Accounting Review 36 (3): 251268.

Abeysekera, I. 2007. Intellectual capital reporting between a developing and developed nation. Journal of Intellectual Capital 8 (2): 329-345.

Abeysekera, I. 2008. Intellectual capital disclosure trends: Singapore and Sri Lanka. Journal of Intellectual Capital 9 (4): 723-737.

Abeysekera, I. and Guthrie, J. 2005. An empirical investigation of annual reporting trends of intellectual capital in Sri Lanka". Critical Perspectives on Accounting 16 (3): 151-163.

Ahmed, A. A. and Dey, M. M. 2009. An Empirical Analysis of Performance Measurement of the Disclosure in Financial Reporting: A Study of Banking Sector in Bangladesh. Paper presented at the 2nd COMSATS International Business Research Conference, COMSATS Institute of Information Technology, 14 November 2009, Lahore, Pakistan.

Akhtaruddin, M. 2005. Corporate mandatory disclosure practices in Bangladesh. The International Journal of Accounting 40 (4): 399-422.

Ali, M.M, Khan, M.H.U.Z, and Fatema, Z. K. 2008. Intellectual Capital (IC) Reporting Practices: A Study on Selected Companies in Bangladesh. Journal of Business Studies 29 (1): 81-104. 
Andriessen, D. 2004. IC valuation and measurement: Classifying the state-of-the-art. Journal of Intellectual Capital 5 (3): 230-242, cited in Bruggen, A., Vergauwen, P. and Dao, M. 2009. Determinants of intellectual capital disclosure: evidence from Australia. Management Decision 47 (2): 233-245.

April, K.A., Bosma, P. and Deglon, D.A. 2003. IC measurement and reporting: establishing practice in SA mining. Journal of Intellectual Capital 4 (2): 165-180.

Batista Fontana, F. and Macagnan, C.B. 2013. Factors explaining the level of voluntary human capital disclosure in the Brazilian capital market. Intangible Capital 9 (1): 305-321.

Bhuiyan, M.H.U. and Biswas, P.K. 2007. Corporate Governance and Reporting: An Empirical Study of the Listed Companies in Bangladesh. Journal of Business Studies 28 (1).

Bontis, N. 1998. Intellectual Capital: an exploratory study that develops measures and models. Management Decision 36 (2): 63-76

Bontis, N. 2003. Intellectual capital disclosure in Canadian corporations. Journal of Human Resource Costing $\mathcal{E}$ Accounting 7 (1): 9-20.

Bontis, N., Keow, W. C. C., and Richardson, S. 2000.) Intellectual capital and business performance in Malaysian industries. Journal of Intellectual Capital 1: 85100, cited in Khalique, M., Shaari, J.A.N., Isa, A.H.M. and Ageel, A. 2011. Role of Intellectual Capital on the Organizational Performance of Electrical and Electronic SMEs in Pakistan. International Journal of Business and Management 6 (9): 253-257.

Bozzolan, S., Favotto, F. and Ricceri, F. 2003. Italian annual intellectual capital disclosure. Journal of Intellectual Capital 4 (4): 543-558.

Brennan, N. 2001. Reporting intellectual capital in annual reports: evidence from Ireland. Accounting, Auditing and Accountability Journal 14 (4): 423-436.

Bruggen, A., Vergauwen, P. and Dao, M. 2009. Determinants of intellectual capital disclosure: evidence from Australia. Management Decision 47 (2): 233-245.

Chander, S. and Mehra, V. 2011 A study on intangible assets disclosure: An evidence from Indian companies. Intangible Capital 7 (1): 1-30.

Chen, Mei-Chun. 2001. The effect on enterprise performance by information technology investment and intellectual capital. Ph.D. thesis, Department of Information Management, National Central University, Taiwan, cited in $\mathrm{Wu}$, MeiFen, Lee, Yu-Je and Wang, Gao-Liang. 2012. To Verify How Intellectual Capital Affects Organizational Performance in Listed Taiwan IC Design Companies with Considering the moderator of Corporate Governance. The Journal of Global Business Management 8 (1), retrieved from www.jgbm.org, on June 12, 2014.

Córcoles, Yolanda Ramírez. 2013. Importance of intellectual capital disclosure in Spanish universities. Intangible Capital 9 (3): 931-944.
Davey, J., Schneider, L. and Davey, H. 2009. Intellectual capital disclosure and the fashion industry. Journal of Intellectual Capital 10 (3): 401-442.

Dhaka Stock Exchange (DSE). 2008. Monthly Review 23 (6). Dhaka

Dumay, J.C. 2009. Intellectual capital measurement: a critical approach. Journal of Intellectual Capital 10 (2): 190-210.

Edvinsson, L., and Malone, M. 1997. Intellectual Capital: Realising Your Company's True Value by Finding its Hidden Brainpower, New York: Harper Business (a division of Harper Collins Publishers).

Goh, P.C. and Lim, K.P. 2004. Disclosing intellectual capital in company annual reports: evidence from Malaysia. Journal of Intellectual Capital 5 (3): 500-510.

González-Loureiro, M. and Dorrego, P. F. 2012. Intellectual Capital and System of Innovation: What really Matters at Innovative SMEs. Intangible Capital 8 (2): 239-274, http://dx.doi.org/10.3926/ic.273.

Guthrie, J. and Petty, R. 2000. Intellectual capital: Australian annual reporting practices. Journal of Intellectual Capital 1 (3): 241-251.

Guthrie, J., Petty, R. and Ricceri, F. 2007. Intellectual capital reporting: Lessons from Hong Kong and Australia. available at http://www.icas.org.uk/site/cms/download/res_Guth rie_Report.pdf, accessed on June 6, 2011.

Guthrie, J., Steane, P. amd Farneti, F. 2009. IC reporting in the Australian Red Cross blood service. Journal of Intellectual Capital 10 (4): 504-519.

Hossain, D.M., Amirus, S. and Al-Amin. 2005. Voluntary Disclosure on Corporate Social Responsibility: A Study on the Annual Reports of Bangladeshi Companies. The Bangladesh Accountant 47 (20).

Hossain, D.M., Khan, A.R. and Yasmin, I. 2004. The Nature of Voluntary Disclosure on Human Resource in the Annual Reports of Bangladeshi Companies. Dhaka University Journal of Business Studies 25 (1): 221-231.

Hossain, M. A. 1999. Disclosure of Information in Corporate Annual Reports of Listed Non-financial Companies in Developing Countries: A comparative Study of India, Pakistan and Bangladesh. Unpublished Ph.D. Thesis, School of Accounting and Finance, The Manchester University.

Hossain, M. A., Islam, M. K. S., and Andrew, J. 2006. Corporate Social and Environmental Disclosure in Developing Countries: Evidence from Bangladesh. Retrieved from http://ro.uow.edu.au/commpapers /179.

Hossain, M. M. 2011. Intellectual Capital Disclosure by the Listed Fuel \& Power and Engineering Firms in Bangladesh. Asian Accounting and Auditing Advancement 1 (3): 221-243.

Hossain, M. M. 2012. Financial Statement of Banks under Islamic Shariah: Status of Regulatory Compliance. Thoughts on Economics 22 (1): 53-67. 
Hossain, M. M. 2015. Corporate Governance and Intellectual Capital Reporting in Corporate Annual Reports of Emerging Economies: An Empirical Investigation of Listed Companies in Bangladesh. Unpublished Ph.D. Dissertation, Institute of Business Administration, Rajshahi University.

Hossain, M. M. and Khatun, M. 2014. Disclosure Compliance of Islamic Banks in Bangladesh: Local and International Regulatory Perspective. Journal of Islamic Economics, Banking and Finance 10 (4): 74-88.

Hossain, M.A and Taylor, P.J. 1998. Extent of disclosure in corporate annual report in developing countries: A comparative study of India, Pakistan and Bangladesh. Paper presented to the Cardiff School Business School Conference in Financial Reporting (held in 6-7 July), cited from Akhtaruddin, M. 2005. Corporate mandatory disclosure practices in Bangladesh. The International Journal of Accounting 40 (4): 399-422.

Hossain, M.A, Cooper, K, and Islam, K.S. 2006. Compliance with IASs: The Case of Bangladesh. Paper presented at the Seventh Asian Accounting Association Conference, 17th19th September, Sydney, Australia.

Hossain, M.A. 2000. An evaluation of the international accounting standards in developing countries: A case study of Bangladesh. An Unpublished Research Report, Faculty of Business Studies, Rajshahi University, cited from Akhtaruddin, M. 2005. Corporate mandatory disclosure practices in Bangladesh. The International Journal of Accounting 40 (4): 399-422.

Islam, M. 2006. Compliance with Disclosure Requirements by Four SAARC Countries-Bangladesh, India, Pakistan and Sri Lanka. Journal of American Academy of Business 10 (1): 348-356.

Johnson, K. 1999. Making loyalty program more rewarding Direct Mark 61 (11): 24-27, cited in Wu, MeiFen, Lee, YuJe and Wang, Gao-Liang. 2012. To Verify How Intellectual Capital Affects Organizational Performance in Listed Taiwan IC Design Companies with Considering the moderator of Corporate Governance. The Journal of Global Business Management 8 (1), retrieved from www.jgbm.org, on June 12, 2014.

Joshi, M., Ubha, D.S., and Sidhu, J. 2010. Reporting Intellectual Capital In Annual Reports From Australian S/W \& I/T Companies. Journal of Knowledge Management Practice 11 (3), accessed from www.tlainc.com/articl236.htm, on June 5, 2011.

Karim, A.K.M.W. 1995. Provision of Corporate Financial Information in Bangladesh. Unpublished PhD Thesis, The University of Leeds, UK.

Kavida, V and Sivakoumar, N. 2009. Intellectual Capital: A Strategic Management Perspective. The ICFAI Journal of Knowledge Management 7 (5/6): 55-69.

Khan, M.H.U.Z and Khan, M.R. 2010. Human capital disclosure practices of top Bangladeshi companies. Journal of Human Resource Costing E Accounting 14 (4): 329 -349 .
Knight, D. J. 1999. Performance Measures for Increasing Intellectual Capital. Strategy \& Leadership 27 (2): 22-25 cited in $\mathrm{Wu}$, MeiFen, Lee, Yu-Je and Wang, Gao-Liang. 2012. To Verify How Intellectual Capital Affects Organizational Performance in Listed Taiwan IC Design Companies with considering the moderator of Corporate Governance. The Journal of Global Business Management 8 (1), retrieved from www.jgbm.org, on June 12, 2014.

Lipunga, A.M. 2013. Visualization of Intellectual Capital disclosures in annual reports of commercial banks of Malawi. Interdisciplinary Journal of Contemporary Research in Business 5 (3): 155-169.

Majdalany, G. and Henderson, J. 2013. Voluntary disclosure of intellectual assets and intellectual liabilities: Impact on financial performance in publicly listed firms in the United Arab Emirates. Electronic Journal of Knowledge Management 11 (4): 325-338, available at www.ejkm.com.

Nurunnabi, M., Hossain, M.A. and Hossain, M.M. 2011. Intellectual capital reporting in a South Asian country: Evidence from Bangladesh. Journal of Human Resource Costing \& Accounting (JHRCA) 15 (3): 196-231.

Oliveira, L., Rodrigue L. L. and Craig, R. 2006. Firm-specific determinants of intangibles reporting: evidence from the Portuguese stock market. Journal of Human Resource Costing $\mathcal{E}$ Accounting 10 (1): 11-33.

Orens, R., Aerts, W, and Lybaert, N. 2009. Intellectual capital disclosure: cost of finance and firm value. Management Decision 47 (10): 1536-1554.

Ortiz, M.A.A. 2009. Analysis and valuation of intellectual capital according to its context. Journal of Intellectual Capital 10 (3): 451-482.

Pandit, A. C., Hossain, M. M. and Khatun, M. 2011. Disclosure Requirements of Banks: Bangladesh Perspective. Banking Research Series 2011, Paper 3, pp. 71-116, BIBM, Dhaka.

Rahman, M.M. 1999. The Extent of Mandatory and Voluntary Financial Disclosure by Listed Companies in Bangladesh. Dhaka University Journal of Business Studies 20 (1): 189-208.

Rouf, M. A. and Hossain, M. M. 2011. The Corporate Social Responsibility Disclosure: A Study of Listed Companies in Bangladesh. Bank Parikrama, Vol. 35 \& 36, pp. 78-99.

Stewart, T.A. 1997. Intellectual Capital: The New Wealth of Organizations, Nicholas Brealey, London.

Sujan, A and Abeysekera, I. 2007. Intellectual capital reporting practices of the top Australian firms. Australian Accounting Review 17 (2): 71-83.

Sveiby, K.E. 1997. The New Organizational Wealth: Managing and Measuring Knowledge-Based Assets, Berrett-Koehler Publishers, Inc. San Francisco.

Tovstiga, G. and Tulugurova, E. 2009. Intellectual capital practices: a four-region comparative study. Journal of Intellectual Capital 10 (1): 70-80.

Vandemaele, S.N., Vergauwen, P.G.M.C., and Smits, A.J. 2005. Intellectual capital disclosure in The Netherlands, Sweden and the UK: A longitudinal and comparative study. Journal of Intellectual Capital 6 (3): 417-426. 
Verbano, C. and Crema, M. 2013. Measuring IC following a semi-qualitative approach: An integrated framework. Intangible Capital 9 (3): 539-558, retrieved from http://dx.doi.org/10.3926/ic.427.

Vergauwen, P.G.M.C. and van Alem, F.J.C. 2005. Annual report IC disclosures in The Netherlands, France and Germany. Journal of Intellectual Capital 6 (1): 89-104.

Wallace, R. S. O. 1988. Corporate financial reporting in Nigeria. Accounting and Business Research 18 (72): 352-362, cited in Akhtaruddin, M. 2005. Corporate mandatory disclosure practices in Bangladesh. The International Journal of Accounting 40 (4): 399-422.

Wong, M. and Gardner, C. 2005. Intellectual capital disclosure: New Zealand evidence. AFAANZ, available at: www.afaanz.org /web2005/papers/ gardnerc.pdf, accessed on April 20, 2010.
Wu, MeiFen, Lee, Yu-Je and Wang, Gao-Liang. 2012. To Verify How Intellectual Capital Affects Organizational Performance in Listed Taiwan IC Design Companies with Considering the moderator of Corporate Governance. The Journal of Global Business Management 8 (1), retrieved from www.jgbm.org, on June 12, 2014.

Xiao, H. 2008. Corporate Reporting of Intellectual Capital: Evidence from China. The Business Review 11 (1): 124-129.

Xinyu, Z. 2014. The impacts of intellectual capital of China's public pharmaceutical company on company's performance. Journal of Chemical and Pharmaceutical Research 6 (4): 999-1004, available at www.jocpr.com.

Zéghal, D. and Maaloul, A. 2010. Analysing value added as an indicator of intellectual capital and its consequences on company performance. Journal of Intellectual Capital 11 (1): 39-60. 


\section{APPENDIX}

HC Disclosure Items with Reference

\begin{tabular}{|c|c|c|}
\hline $\mathrm{S} / \mathrm{N}$ & IC Item & Reference \\
\hline 1 & Know-how and work-related competencies & $\begin{array}{l}\text { April, Bosma and Deglon (2003); } \\
\text { Goh and Lim (2004); } \\
\text { Lipunga (2013) }\end{array}$ \\
\hline 2 & Vocational qualifications & $\begin{array}{l}\text { Abeysekera and Guthrie (2005); } \\
\text { Ali, Khan and Fatema (2008); } \\
\text { Davey, Schneider and Davey (2009) }\end{array}$ \\
\hline 3 & Career and Development & $\begin{array}{l}\text { Dumay (2009); } \\
\text { Macagnan (2009); } \\
\text { Lipunga (2013) }\end{array}$ \\
\hline 4 & Training Programs & $\begin{array}{l}\text { Guthrie, Steane and Farneti (2009); } \\
\text { Chander and Mehra (2011); } \\
\text { Córcoles (2013) }\end{array}$ \\
\hline 5 & Equity Issue (Race, Gender and Religion) & $\begin{array}{l}\text { Macagnan (2009); } \\
\text { Chander and Mehra (2011); } \\
\text { Batista Fontana and Macagnan (2013) }\end{array}$ \\
\hline 6 & Equity Issue (Disability) & $\begin{array}{l}\text { Abeysekera and Guthrie (2004); } \\
\text { Hossain (2011); } \\
\text { Nurunnabi, Hossain and Hossain (2011) }\end{array}$ \\
\hline 7 & Employees being thanked and Featured & $\begin{array}{l}\text { Abeysekera and Guthrie (2005); } \\
\text { Abeysekera (2007); } \\
\text { Guthrie, Steane and Farneti (2009); }\end{array}$ \\
\hline 8 & Employee involvement in the community & $\begin{array}{l}\text { Guthrie, Steane and Farneti (2009); } \\
\text { Macagnan (2009); } \\
\text { Hossain (2011); }\end{array}$ \\
\hline 9 & Employee and executive compensation & $\begin{array}{l}\text { Abeysekera and Guthrie (2004); } \\
\text { Hossain (2011); } \\
\text { Batista Fontana and Macagnan (2013) }\end{array}$ \\
\hline 10 & Employee benefits other than salary & $\begin{array}{l}\text { Abeysekera and Guthrie (2004); } \\
\text { Macagnan (2009); } \\
\text { Nurunnabi, Hossain and Hossain (2011); }\end{array}$ \\
\hline 11 & Employee share and option ownership plan & $\begin{array}{l}\text { Abeysekera (2007); } \\
\text { Hossain (2011); } \\
\text { Nurunnabi, Hossain and Hossain (2011) }\end{array}$ \\
\hline 12 & Value-added statement & $\begin{array}{l}\text { Hossain (2011); } \\
\text { Nurunnabi, Hossain and Hossain (2011); } \\
\text { Lipunga (2013) }\end{array}$ \\
\hline 13 & Employee and their numbers & $\begin{array}{l}\text { Bozzolan, Favotto and Ricceri (2003); } \\
\text { Macagnan (2009) } \\
\text { Davey, Schneider and Davey (2009); }\end{array}$ \\
\hline 14 & Professional experience of the employee & $\begin{array}{l}\text { Abeysekera and Guthrie (2005); } \\
\text { Córcoles (2013); } \\
\text { Lipunga (2013) }\end{array}$ \\
\hline 15 & $\begin{array}{l}\text { Educational and professional qualification of member of the board } \\
\text { and company secretary }\end{array}$ & $\begin{array}{l}\text { April, Bosma and Deglon (2003); } \\
\text { Guthrie, Steane and Farneti (2009); } \\
\text { Hossain (2011) }\end{array}$ \\
\hline 16 & Expert seniority & $\begin{array}{l}\text { Hossain (2011); } \\
\text { Nurunnabi, Hossain and Hossain (2011); } \\
\text { Batista Fontana and Macagnan (2013) }\end{array}$ \\
\hline 17 & Age of employees & $\begin{array}{l}\text { Macagnan (2009); } \\
\text { Davey, Schneider and Davey (2009); } \\
\text { Guthrie, Steane and Farneti (2009); }\end{array}$ \\
\hline 18 & Entrepreneurial spirits & $\begin{array}{l}\text { Goh and Lim (2004); } \\
\text { Sujan and Abeysekera (2007); } \\
\text { Davey, Schneider and Davey (2009); }\end{array}$ \\
\hline 19 & Employee safety and work environment & $\begin{array}{l}\text { Dumay (2009); } \\
\text { Macagnan (2009) } \\
\text { Batista Fontana and Macagnan (2013); }\end{array}$ \\
\hline
\end{tabular}

Source: Researchers' own compilation 
How to Cite: Hossain, M., \& Uddin, M. (2018). Human Capital Disclosure by the Listed Non-Financial Companies of Bangladesh. American Journal of Trade and Policy, 5(3), 99-112.

\section{SOCIAL SCIENCE RESEARCH NETWORK}

2171 Monroe Avenue, Suite 203, Rochester, NY 14618, USA

http://www.ssrn.com/en/

SSRN Link: http://www.ssrn.com/link/American-Journal-Trade-Policy.html 